\title{
Listanje Sarajevskih zvezkov v spominskem zrcalu
}

Boris A. Novak

Filozofska fakulteta Univerze v Ljubljani, Oddelek za primerjalno književnost in literarno teorijo, Aškerčeva 2, 1000 Ljubljana

boris-a.novak@guest.arnes.si

\begin{abstract}
Članek je posvečen zgodovini Sarajevskih zvezkov, pogumnega, umetniško in intelektualno ambicioznega projekta ponovne graditve komunikacijskih mostov med pisatelji različnih narodov nekdanje Jugoslavije, ki so se po tragičnih vojnah znašli ločeni z visokimi mejami novonastalih držav. Avtor, slovenski pesnik, prevajalec in profesor primerjalne književnosti, je bil eden izmed ustanounih članov uredništva te publikacije. Ustanovitelji Sarajevskih zvezkov, ki sodijo med najboljše pisatelje in intelektualce svojih jezikov in kultur, niso imeli nikakršnega namena oživljati propadlo Jugoslavijo ali pa ustanoviti novo, tretjo Jugoslavijo (po kraljevini in socialistični federativni republiki). Njihova ambicija je bila v političnem smislu neprimerno skromnejša, v umetniškem, intelektualnem in etičnem smislu pa kar najvišja - literarno artikulirati stanje sveta ter eksistencialno počutje posameznika po koncu velikih utopičnih zgodb, razpadu jugoslovanskega projekta "bratstva in enotnosti ter padcu socializma, velikega političnega projekta 20. stoletja, ki je najprej ideološko skrepenel v totalitaristično strahovlado, spričo spodletele demokratizacije pa se je v obdobju jugoslovanskih vojn še zadnjič vrnil kot vampir krvoločnega nacionalizma.
\end{abstract}

Ključne besede: literatura in politika / Jugoslavija / jugoslovanske književnosti / literarne revije / Sarajevski zvezki / Evropa / Balkan / kulturna zgodovina / kulturna identiteta / nacionalizem / emigracija

spominu Bogdana Bogdanovića, Jozefine Dautbegović, Aleša Debeljaka, Dašs Drndić, Vojke Smiljanić Đikić,

Mirka Kovača, Nikole Kovača, Turtka Kulenovića, Tarasa Kermaunerja, Predraga Matvejevića, pokojnim članicam in članom redakcije, sodelavkam in sodelavcem Sarajevskih zvezkov

Ne more biti nobenega dvoma, da so Sarajevski zvezki najboljša jugoslovanska literarna revija vseh časov - paradoks tega prvenstva pa je v dejstvu, da so se Sarajevski zvezki zgodili šele po krvavi in tragični 
vojni, ki je v devetdesetih letih razdejala Jugoslavijo. Še več: Sarajevski zvezki so postali možni šele po razpadu Jugoslavije, po padcu političnega sistema, ki je zapovedoval »bratstvo in enotnost« tudi na področju kulture in umetnosti. Pri književnosti je ta ideološka floskula trčila ob trdovratno bariero - jezikovne razlike. Ni naključje, da se je proces boja za samostojnost Slovenije začel v zgodnjih osemdesetih letih prejšnjega stoletja, ko je jugoslovanska partijska nomenklatura, odtrgana od stvarnosti, v paničnem strahu pred prihodnostjo po Titovi smrti lansirala koncept »skupnih jeder" pouka književnosti na celotnem ozemlju Jugoslavije, ki bi imel pogubne posledice za pouk slovenske književnosti, saj bi bila velika večina imen slovenske literarne zgodovine kratko malo izbrisana.

Narava nekdanje federacije je sicer narekovala obstoj "zveznih", "vsejugoslovanskih" kulturnih revij; prav zaradi dejstva, da so bile te revije politično motivirane in kontrolirane, pa niso bile kvalitetne; $v$ njih so objavljali "uradni" pisatelji, v avtentičnih pisateljskih krogih pa niso veliko pomenile. Kvalitetne literarne revije so nastajale na polju "nacionalnih" kultur. In če so bile kvalitetne, so bile tudi odprte do drugih kultur ter prej ali slej obsojene na spopad s političnim sistemom, včasih pa tudi s kazenskim zakonikom, kot v primeru serije slovenskih disidentskih revij Beseda, Revija 57 in Perspektive.

Paradoks kulturnega in umetniškega življenja v Jugoslaviji je bil, da t. i. jugoslovanske kulture nikoli ni bilo oziroma točneje: da je šlo za ideološki konstrukt, ki ni imel pokritja v stvarnosti jezikovnih, kulturnih in religioznih razlik kompleksne in nasprotij polne jugoslovanske državne tvorbe. Še večji paradoks s presenetljivo pozitivnimi umetniškimi in kulturnimi posledicami pa je bil, da so prav kulturne razlike izžarevale tisto vrednost, ki je bila v Jugoslaviji najzanimivejša in najplodnejša. Če je "jugoslovanska kultura" sploh kje bila, je bila - paradoksalno - prav $\mathrm{v}$ razlikah, $\mathrm{v}$ spoštovanju in čudenju drugim in drugačnim, prav zaradi razlik navdihujočim kulturam. Jugoslavija je bila svet $\mathrm{v}$ malem, zato je preseganje ozkih meja nacionalnih kultur pomenilo odpiranje $\mathrm{v}$ širši prostor, $\mathrm{k}$ drugim in drugačnim obzorjem.

Pomenljivo je dejstvo, da je pobuda za to revijo kmalu po koncu jugoslovanskih vojn prišla prav iz Sarajeva, mesta, ki je bilo izpostavljeno nečloveškemu trpljenju v letih 1992-95, in da smo vsi ustanovitelji takoj in s prepričanjem podprli naslov Sarajevski zvezki.

20. stoletje se je začelo in končalo prav v Sarajevu: strašni začetek najbolj strašnega stoletja $v$ dosedanji zgodovini je bil atentat Gavrila Principa na nadvojvodo Franca Ferdinanda 1. 1914 v Sarajevu, kjer se je strašno stoletje tudi končalo $\mathrm{z}$ nekajletnim obleganjem. Zgodovina 
Jugoslavije je bila zgodovina 20. stoletja $\mathrm{v}$ malem: rodila se je po prvi svetovni vojni l. 1918, umrla pa je $\mathrm{v}$ agoniji jugoslovanskih vojn $\mathrm{v}$ devetdesetih letih: obe osmrtnici, tako Jugoslaviji kot 20. stoletju, so pisali ostrostrelci, ki so $s$ hribov okoli Sarajeva pobijali civiliste, svoje dovčerajšnje sosede.

Zato ni moglo biti drugače, kot da se revija, ki je po krvavem razpadu Jugoslavije ponovno zbrala cvet avtoric in avtorjev različnih narodnosti nekdanje federalne države, imenuje Sarajevski zvezki, s sedežem redakcije - kje neki? - prav v Sarajevu. S tem simboličnim imenom smo člani/-ce redakcije ter vse sodelujoče avtorice in avtorji izrazili spoštovanje Sarajevu kot prestolnici bolečine, kar je že samo po sebi impliciralo kritiko nacionalističnih ideologij, ki so povzročile tragične vojne.

In ker so te vojne s svojo krvavo pisavo nazorno pokazale, kam pelje politična absolutizacija principa ene in edine nacije ter zatiranje drugih, smo ime revije na naslovnicah vseh številk vselej natisnili večjezično: $\mathrm{z}$ belimi majuskulami na sivi podlagi smo dali enak poudarek petim jezikovnim variantam, ki smo jih vseskozi doživljali kot enakopravne: Sarajevske sveske (bosansko) - Sarajevske bilježnice (hrvatsko) Сарајевске свеске (srbsko) - Sarajevski zvezki (slovensko) - Сараевски тетратки (makedonsko), na naslovnici pa je vselej bil natisnjen tudi angleški prevod Sarajevo Notebook ter prevodi v devet drugih jezikov.

Pobudnica Sarajevskih zvezkov je bila gospa Vojka Smiljanić Đikić (1932-2016), bosanska pesnica, prevajalka in publicistka. Pomembne so njene pesniške zbirke Pepelnica (1997), Druga dežela (Druga zemlja, 2000) in Prevajanje morja (Prevođenje mora, 2004), še posebej pa velja omeniti baladno pesnitev Knjiga mrtvih Smiljanićev v Sarajevu (SZ, št. 32-33, 2011), pretresljivo spominsko pričevanje o strašni usodi večine Vojkinih prednikov in sorodnikov, ki so jih nacisti pobili med drugo svetovno vojno. Ta pesnitev se s svojo tragično intonacijo vpisuje $\mathrm{v}$ veliko tradicijo balad in elegij v bosanski literarni zgodovini, kakršna je Stojanka, mati Knežopoljka Skenderja Kulenovića.

Okoli Vojke Smiljanić Đikić je stal krog vrhunskih bosanskih pisateljev in intelektualcev. Dobro sem jih poznal, z nekaterimi sem sodeloval in prijateljeval že pred vojno, vsi pa so bili na seznamu humanitarne pomoči, ki sem jo organiziral, najprej v imenu Slovenskega, potem pa tudi Mednarodnega Pena. Svetovna pisateljska organizacija jo obravnava kot eno izmed največjih humanitarnih akcij v svoji zgodovini.

Skozi celotno zgodovino Sarajevskih zvezkov je Vojka Smiljanić Đikić požrtvovalno in inovativno igrala vlogo izvršne urednice, funkcijo glavnega in odgovornega urednika pa je nadvse odgovorno, korektno in z velikim posluhom za vse mogoče razlike med člani redakcije in 
sodelavci opravljal Velimir Visković, hrvaški literarni zgodovinar in publicist, sicer univerzitetni profesor in visoko profilirani urednik Hrvaške enciklopedije. Med ustanovitelji Sarajevskih zvezkov sva bila tudi Aleš Debeljak in podpisani, pozneje pa se je pridružil tudi Mitja Čander.

Že pred izidom prve številke je Vojka s svojimi diplomatskimi sposobnostmi in izjemno prepričljivostjo priskrbela finančno podporo Bosne in Hercegovine, Švedske, Norveške, Finske, Švice, Francije, Portugalske, Španije in Velike Britanije. Še posebej pomembna je bila $\mathrm{v}$ naslednjih letih izdatna norveška subvencija, sicer v okviru pogodbe med to skandinavsko državo in Evropsko unijo, po kateri je Norveška kompenzirala dostop na evropski trg s subvencioniranjem kulturnih projektov. Izdajatelj Sarajevskih zvezkov je bil Mediacentar Sarajevo, katerega direktor Boro Kontić je bil strastno predan našemu projektu. Slovenija se je tudi plodno vključila v to podporno mrežo; nekaj let je bila pomoč Slovenije ključna tudi organizacijsko in logistično. Pri tem velja hvaležno omeniti razumevanje, ki sta ga za potrebe Sarajevskih zvezkov izkazala dr. Dimitrij Rupel kot zunanji minister RS in dr. Janez Potočnik kot komisar Evropske komisije za širitev EU, znanost in okolje, zato sta $\mathrm{z}$ uvodnikoma nagovorila mednarodno občinstvo v obeh angleških številkah Best of Sarajevo Notebooks - Rupel v številki 18 (2008), Potočnik pa v številki 34 (2011). V tem obdobju je velik del skrbi za organizacijo in logistiko prevzela Študentska založba (Beletrina), sedež uredništva pa je še ostal v Sarajevu. Za gladko funkcioniranje te mednarodne revije, ki je delovala $\mathrm{v}$ zelo kompleksnih in kompliciranih mednarodnih razmerah, si je z velikim čutom odgovornosti in z brezhibno profesionalnostjo prizadeval Mitja Čander kot "dvojni agent" Beletrine in Sarajevskih zvezkov.

Finančna podpora različnih držav, ki je bila v prvih letih spodobna (prispevki so bili celo honorirani), je polagoma, iz leta v leto, kopnela. Sestava redakcije se je menjavala in se skozi leta tudi večala. Nekateri člani in članice so zaradi različnih razlogov, tudi političnih, izstopili iz uredništva, vendar je treba priznati, da smo kljub različnim pogledom na določena vprašanja delovali kot nenavadno dobro uigrana ekipa. Razlike v pogledih smo večinoma zdržali modro in dostojanstveno, pogosto tudi z dobršno mero humorja, ironije in avtoironije. Prioriteta, ki smo jo vsi čutili kot kategorični imperativ, je bila ponovno navezovanje pretrganih literarnih, kulturnih in osebnih vezi. V primerjavi s tem imperativom so bile estetske in ideološke razlike manj važne.

Zaradi finančnih in organizacijskih razlogov so bile številke izjemno obsežne; sleherna med njimi je pravzaprav tvorila zbornik, in tej nujnosti smo prilagodili tudi uredniški koncept rubrik. Največji problem 
je bila distribucija številk, saj zaradi pretrganih komunikacijskih mrež in pomanjkanja sredstev pošiljanje izvodov po pošti ter njihova prodaja po knjigarnah novih državnih prestolnic ni bila mogoča; zato smo morali nenehno tihotapiti te izjemno težke izvode čez nove državne meje in jih deliti objavljenim sodelavcem, knjižnicam in novinarjem.

$\mathrm{Tu}$ so imena članic in članov redakcije v različnih obdobjih, navedena po abecednem zaporedju tako držav kot priimkov:

- iz BiH publicisti in univerzitetni profesorji Zdravko Grebo, Enver Kazaz in Tvrtko Kulenović, pisatelj Dževad Karahasan, kritik, prevajalec in diplomat Nikola Kovač, pisateljica Alma Lazarevska, literarna zgodovinarka Andrea Lešić, publicist Senadin Musabegović, prevajalec Zoran Mutić ter pesnik Marko Vešović;

- iz Črne Gore pesnik Balša Brković in pisatelj Andrej Nikolaidis;

$-s$ Kosova pesnik in publicist Basri Kapriqi;

- iz Makedonije pesnica Ljiljana Dirjan, pesnica in literarna komparativistka Elizabeta Šeleva ter publicist Robert Alagjozovski;

- s Hrvaške zgodovinar Ivo Banac, pesnica Ana Brnardić Oproiu, pisateljici Daša Drndić in Ivica Duhović-Žaknić, pisatelj Miljenko Jergović (sicer rojen v Sarajevu), pisateljica in profesorica književnosti Julijana Matanović, pesnica in pisateljica Sibila Petlevski ter dramatik Slobodan Šnajder;

- iz Slovenije pesnik in profesor sociologije Aleš Debeljak, urednik in publicist Mitja Čander ter podpisani;

- iz Srbije pesnik Jovica Aćin, pisateljica Ljubica Arsić, literarni zgodovinar Tihomir Brajović, prevajalka Drinka Gojković, publicist Zoran Hamović, esejistka in prevajalka Milica Nikolić, pisatelj Radoslav Petković, pisatelj in profesor književnosti Mihajlo Pantić, publicistka in univerzitetna profesorica Tatjana Rosić, umetnostni teoretik Miško Šuvaković, pesnik in literarni zgodovinar Gojko Tešić ter pisatelj Dragan Velikić.

Sekretar redakcije je najprej bil Zoran Mutić (odličen prevajalec, ki je zavetje pred vojno našel v Ljubljani, po vojni pa je bil prevajalec Sodišča za vojne zločine na območju nekdanje Jugoslavije v Haagu), nato pa dolgo vrsto let prijazna Aida El Hadari-Pediša. Vesel sem, da se je našega simpozija udeležil tudi briljantni prof. dr. Tihomir Brajović z Univerze v Beogradu, dvojni kolega, tako po stroki kot po redakciji Sarajevskih zvezkov.

Prva številka je izšla l. 2002; v embrionalni obliki je vsebovala celoten konceptualni diapazon Sarajevskih zvezkov. Visković je v "Uvodniku" zapisal: 
Nacionalistične elite, ki so imele svoje ideologe prav v literarnih krogih, so vsilile "govorico sovraštva" kot zaželen model odnosa do sosednjih, dovčerajšnjih t. i. bratskih narodov. Po koncu vojn se na teh tleh še zmeraj vzdržuje stanje »hladne vojne« na področju kulturnih stikov. (Visković, »Uvodnik«7)

Ena izmed stalnih rubrik Sarajevskih zvezkov je bila Dialog. Že v prvi številki sta Dane Zajc in Aleš Debeljak visoko postavila kriterije literarne vrednosti in osebne iskrenosti tovrstnega dialoga. $V$ drugi številki, ki je izšla 1. 2003, sledi Dialog srbskih pisateljev Davida Albaharija in Mihajla Pantića.

Od druge številke naprej je značilnost Sarajevskih zvezkov vsakokratni tematski sklop. Prvi med njimi je posvečen Ženski pisavi, kar je vzpostavilo nujno potrebno protiutež divjanju patriarhalnega nasilja $\mathrm{v}$ jugoslovanskih vojnah. (Ob tem le pripomba: feministično gibanje se je v prostorih nekdanje Jugoslavije nujno soočilo $s$ strašnim moralnim bremenom množičnih posilstev, ki so prisilila mednarodno pravo, da posilstvo prvič v zgodovini opredeli kot vojni zločin.) Sklop je pripravila ter uvodno razmišljanje prispevala Jelena Lukić ("Žensko pisanje in ženska pisava v devetdesetih letih «), Andrea Zlatar je analizirala poetiki hrvaških pisateljic Irene Vrkljan in Daše Drndić, Lada Čale Feldman se je posvetila adaptaciji Medeje hrvaške dramatičarke Ivane Sajko, Nirman Moranjak Bamburač je v članku »Signature smrti in etičnost ženske pisave« razgrnila položaj bosanskih pisateljic, Vladislava Gordić Petković se je posvetila srbski ženski prozi devetdesetih let, Biljana Dojčinović Nešić romaneskni poetiki Ljubice Arsić, Tatjana Rosić Slovarju Branke Arsić (»Postmoderne strategije zapeljevanja in tradicija/ bodočnost 'ženske pisave' "), Jasna Koteska pa je prispevala razmišljanje "Makedonska ženska književnost od asimbolike k feminizmu".

Nosilni tematski sklop 3. številke (2003) je bil Pisatelji na meji (Pisci na granici), ki sem ga uredil podpisani. V uvodniku v ta tematski blok, naslovljenem "Zakaj 'pisatelji na meji' " ("Zašto 'pisci na granici'«) sem med drugim zapisal:

Identiteta nikoli ni monolitna, zaprta, nespremenljiva, enkrat za vselej dana posamezniku in skupnosti, temveč je večplastna, odprta, kompleksna, spremenljiva. Tematski sklop z naslovom Pisatelji na meji je koncipiran z željo, da damo besedo tistim pisateljem, ki so s svojo osebno in/ali literarno usodo navezani na dva ali več kulturnih prostorov. [...]

Noben narod ni nikoli etnično čist (hvala bogu!). Njegova ustvarjalna moč je odvisna od zmožnosti, da vase vključi druge in tuje elemente ter se na ta način odpre v svet. Absolutizacija etnične čistosti je prizadejala veliko zla prostorom nekdanje Jugoslavije. [...] 
Kljub neizbežnim političnim konotacijam naš namen z objavo tematskega sklopa Pisatelji na meji nikakor ni političen. [...] Države nastajajo in propadajo, po vsaki vojni se zemljevidi menjavajo in popravljajo, notranja geografija pisatelja pa ostaja nespremenjena: njegova čustvena in kulturna izkušnja z določenim življenjskim okoljem ostaja izvir njegovega navdiha. Identiteta ne izvira iz političnih proklamacij, ampak iz kulturnega in čustvenega spomina. [...]

Naslov Pisatelji na meji pa izžareva še en pomen: prepričani smo, da se nove in plodne umetniške in kulturne pobude ne porajajo v središču zgodovinskega dogajanja, ampak na njegovem robu, na meji. (Novak, Pisci 33-35)

Sibila Petlevski, hrvaška pisateljica makedonskega rodu, ki piše tudi $\mathrm{v}$ angleščini, je v boleče iskrenem zapisu "Literarno iskanje izgubljene resnice in identitete« zapisala: "Svojo identiteto doživljam kot pravico do izbora: ne nujno do izbora iz vnaprej ponujenega materiala svoje lastne genetske in kulturne dedišcine. "(54)

Veliki srbski pisatelj in publicist Bora Čosić, avtor duhovitega in pretresljivega, odmevnega romana Vloga moje družine v svetovni revoluciji (1969) ter izjemne teoretične knjige Mixed media (1970), s katero je globoko vplival na jugoslovanska avantgardistična raziskovanja $\mathrm{v}$ sedemdesetih letih, je v šokantnem nasprotju z očarljivim humorjem, ironijo in avtoironijo svojega literarnega in teoretičnega pisanja podal boleče streznjujoč odgovor na strašno vprašanje, ki muči slehernega izgnanca in ki ga je postavil v naslov svojega razmišljanja »Vrnitev iz izgnanstva«:

Zdaj, ko se mnogim ljudem v Srbiji zdi, da je zmagala nekakšna demokracija, me včasih kdo povpraša, ali se bom vrnil tja, v svojo deželo. Zveni, kot bi imel s svojo domovino podpisano nekakšno pogodbo z mnogimi preciznimi postavkami. Katerih se morava držati tako jaz kot država moje preteklosti. In če gredo tam stvari na bolje, da bi se tudi sam moral priključiti temu izboljšanju. Toda ko sem od tam odhajal, nisem, kolikor se spomnim, ničesar podpisal. $[\ldots]$

Potem pa se moram spomniti, v kateri prostor naj bi se sploh vrnil. Zato ker sem del tistih tal, čeprav v najmanjši možni količini, odnesel s seboj, zato tam, na kraju mojega nekdanjega življenja, ni ničesar več. Zato si ves čas predstavljam, da hodim po svojih lastnih tleh, ki so le delno preseljena sem. Gostoljubna tla moje nove dežele na severu so se malce razmaknila, da bi se vanje lahko umestil del mojih starih tal. To se itak dogaja pri dramatičnih preobratih, tistih tektonskih, ko cele planine drsijo v neznano smer, nekdanje doline pa se zapirajo kot strani prebrane knjige. [...]

Zato se jaz ne morem več vrniti v prostor svojega nekdanjega življenja, kakor stari filozof ni mogel dvakrat stopiti v isto reko. (55-57) 
David Albahari je svoj esej »Meje« začel s trenutkom lastnega padca v resnico zgodovine:

O mejah sem začel razmišljati na začetku devetdesetih let prejšnjega stoletja. Pred tem nisem verjel tistim, ki so trdili, da obstajajo. [...] Pisatelj, denimo, se lahko počuti kot Srb ali kot Jud, ne da bi karkoli od tega zaznamovalo prozo ali poezijo, ki jo piše. Kafka je primeren primer: če rečemo, da je bil Jud, ki je v Pragi pisal na nemškem jeziku, kam ga bomo uvrstili? [...] Kadar, denimo, Kundera piše v francoščini, je on češki ali francoski pisatelj? In ko Škvorecki, ki je kanadski državljan, piše v češčini, mar je on etnični kanadski pisatelj, ki obstaja zahvaljujoč politiki multikulturalizma, ali češki pisatelj, ki se ne želi več vrniti domov? (59-62)

Kdor pozna biografski kontekst življenja in dela tega senzibilnega pisatelja, bo seveda razumel, da David Albahari z modro diskretnostjo tu pravzaprav govori o sebi. Po nekaj letih bivanja v Kanadi, kamor se je zatekel v devetdesetih letih, se je Albahari vrnil v Beograd.

Mimogrede: Susan Sontag, ki sem ji pred njenim odhodom v Sarajevo med vojno prek Karen Kennerly, izvršne direktorice Ameriškega Pena, poslal dolgo pismo z natančnimi razlagami boleče kompleksne situacije v obleganem mestu, vključno s seznamom pisateljev, ki smo jim iz Ljubljane pošiljali pomoč, mi je v poznejši korespondenci zatrjevala, da evropske države niso najbolj primerna destinacija za izgnanstvo sarajevskih pisateljev, češ da je kultura starega kontinenta že tako etablirana, da lahko pisateljski imigranti računajo kvečjemu na delo taksistov, ne pa na možnost pisateljskega udejstvovanja. Trdila je, da so za pisatelje na begu najprimernejše tiste države, ki so se pred sto leti tudi same formirale z doseljevanjem ekonomskih in drugih emigrantov - se pravi ZDA, Kanada in Avstralija. Susan Sontag, ta velika duša, se je še posebej angažirala pri iskanju zavetja za narodnostno mešane družine, med drugim pri dramatičnem reševanju mojih dragih prijateljev, štiričlanske družine Gorana in Amele Simić. Amela je bila prevajalka Susan Sontag med njenim bivanjem v obleganem Sarajevu, pesnik Goran Simić pa je kot predsednik srbskega kulturnega društva bil neformalni vodja tistih Srbov, ki so ostali lojalni bosanski vladi. Goran in pesnica Ferida Duraković sta bila požrtvovalna in korektna razdeljevalca pomoči, ki smo jo pošiljali iz Ljubljane.

V tem kontekstu velja s spoštovanjem omeniti velikodušno pomoč, ki jo je v Sarajevo iz Nemčije prinašala Maruša Krese (1947-2013). Zanimivo je, da se je ta izkušnja zapisala bolj v njeno poezijo kot prozo. Šele pred kratkim, 1. 2019, so njene izbrane Pesmi doživele natis v Sloveniji, pri založbi Goga, saj je Maruša Krese vse svoje pesniške zbirke 
objavila v Avstriji, tudi zaradi nestrinjanja z nacionalizmom, ki je po razglasitvi samostojnosti Slovenije dolgo prevladoval v našem kulturnem življenju.

Dragan Velikić, eden izmed tistih srbskih pisateljev, ki so se pogumno uprli Miloševićevi ideologiji in nasilni praksi, je v vrsti svojih romanov artikuliral fenomen tujstva, izgnanstva in tragične nostalgije, začenši že s svojim romanesknim prvencem Via Pula (1990). V "Postscriptumu« k eseju "Meja, identiteta, literatura" Velikić s posluhom detektira domotožje kot eksistencialno stanje izgnancev, ki živijo v dveh stvarnostih hkrati:

Sprehajam se po ulicah Berlina, mesta, v katerem trenutno živim, in nenadoma med fasadami hišs, mimo katerih hodim vsak dan, vznikne hiša, ki je tu nikoli ni bilo, ki je nihče razen mene ne vidi, ker se ta hiša pravzaprav sploh ne nahaja v Berlinu, ampak v Beogradu, mestu, $v$ katerem sem rojen in v katerem sem preživel največji del svojega življenja. Ta hiša je skočila iz preteklosti, ki nikakor ne preteče in ne odteče in se je ugnezdila tukaj, v Berlinu, porajajoč na ta način neko le meni vidno berlinsko ulico, neki le meni dostopen svet. To je torej stvarnost. Niz intimnih prizorov, zbirka privatnih občutkov, nestalna zbirka, ki se vsak dan menjava, ki spreminja tudi mene in mi ne dovoli, da bi zanesljivo vedel, kje sem, v katerem mestu in v katerem času. (70)

Podpisani sem v tematskem bloku Pisatelji na meji sodeloval z esejem "Besede, ki tečejo proti toku časa«, kjer na poetičen način reflektiram svojo razpetost med Beogradom, mestom svojega otroštva, ter Slovenijo svojega poznejšega življenja: "Ne morem drugače, kot da sebe povsem enačim s časom. Jaz sem čas. Odkar se zavedam sebe, se dogajam v času. [...] Jaz sem čas, zgodovina pa se name spušča kakor ptica roparica na svoj plen.« (Novak, »Besede« 125)

Številka 4 (2003) je bila osredotočena na temo Književnost in nacionalistična ideologija. Visković je $\mathrm{v}$ uvodnem eseju s pomenljivim in udarnim naslovom »Ideologi zločina« poudaril:

V osemdesetih letih je bil očiten proces politizacije literarnih, filozofskih, novinarskih in drugih (akademij, PEN klubov itd.) združb intelektualcev. Bilo je jasno, da gre za obdobje krušenja socialističnega družbenega reda, ki je temeljil na vodstveni vlogi komunistične partije, vendar še ni obstajala politična oziroma strankarska infrastruktura, ki bi se pojavila kot alternativa. V tem trenutku so alternativno vlogo prevzele literarne in intelektualne združbe. (65)

Sijajna srbska teatrologinja Mirjana Miočinović, prva žena Danila Kiša, lucidna in pogumna intelektualka, je tu objavila "Poziv k previdnosti v odnosu do pisateljskega poklica«: 
Ta magična avra, ki jo je svet že na veliko snel z glav svojih pisateljev in intelektualcev, poučen z njihovimi velikimi izdajstvi, pa še naprej krasi glave pisateljev iz teh naših prostorov, pa naj si bodo srbski, bošnjaški ali hrvaški, še naprej so neke vrste vrači - ranocelniki, učitelji, ki nam povedo, kaj moramo narediti, ki nam tolmačijo pomen pojavov in vsega, kar se za njimi skriva. (83)

Predrag Matvejević (1932-2017), pisatelj, publicist in mislec mednarodnega formata, katerega Mediteranski brevir je preveden v številne jezike, je bil v jugoslovanskih časih eden izmed pionirjev boja za svobodo izražanja, disidentska vloga pa mu je bila usojena tudi v obdobju samostojne Hrvaške, ko ga je nacionalistično naravnana oblast predsednika Tuđmana sodno preganjala zaradi kritičnih izjav, tako da se je iz Rima, kjer je predaval književnost (tudi slovensko) na slavističnem oddelku univerze La Sapienza, vrnil v Zagreb šele proti koncu življenja. Svoj »Predlog za razmišljanje« je začel in medias res:

Ni prvič v zgodovini Evrope, da se nacionalna kultura sprevrže v ideologijo nacije. Tovrstna ideologija izdaja in ponižuje sámo kulturo. V njenem imenu so se zgodili zločini. [...] Del inteligence, opit z nacionalizmom, nosi krivdo za to, kar se je zgodilo. Imena krivcev nam niso neznana. Živijo med nami. (69)

Klanjam se spominu Predraga Matvejevića. Ure dolgih in vselej prekratkih pogovorov s tem plemenitim, pogumnim, modrim, očarljivim človekom, ponavadi med okusnimi mediteranskimi večerjami v Parizu in Rimu, Zagrebu in Ljubljani, sodijo med lepe ure mojega življenja.

Enako ostra je Slavenka Drakulić, hrvaška pisateljica, ki je bila skupaj z Dubravko Ugrešić in nekaterimi drugimi intelektualkami deležna medijskega linča (imenovali so jih »čarovnice»), češ da izdajajo domovino v času obrambne "domovinske vojne", kar je obe pisateljici pognalo v izgnanstvo:

Radovan Karadžić je zloglasni srbski vojni zločinec, ki ga išče Mednarodno sodišče v Haagu. Obenem je psihiater in pesnik. Edvard Limonov je manj znan od Karadžića, vendar je tudi on prišel na slab glas, potem ko je s strojnico streljal po Sarajevu s hriba nad mestom, o čemer so poročali svetovni mediji. Ni treba poudarjati, tudi on je pesnik. Karadžić ni sam in ni niti izjema. Tekst bi lahko, na primer, pričela tudi s hrvaškim režiserjem Slobodanom Praljkom, ki je ukazal uničenje štiri stoletja starega mostu v Mostarju. (71)

$\mathrm{Na}$ dan zaključka redakcije tega članka sem izvedel, da je "Edička» Limonov umrl. Tudi podleži namreč umirajo.

Filip David, srbski judovski pisatelj in dramaturg, je bil neustrašen kritik Miloševićevega nacional-stalinizma. V članku »Nacionalizem 
kot ideologija» takole detektira "večno vračanje istega» po padcu Miloševića:

Preteklo je že več kot tri leta od padca Miloševićevega režima in zmage 'demokratične revolucije' v Srbiji, še zmeraj pa ni veljavne analize vsega tistega, kar se je dogajalo v temnih časih nacionalističnega populizma, ni javne kritike vloge škodljivcev, ki so jo odigrali vplivni intelektualci, pisatelji, slikarji, glasbeniki, znanstveniki, filozofi pri nastajanju in razvoju režima, odgovornega za nesrečo, ki je zadela velik del nekdanje Jugoslavije. (77)

Filip David se pri analizi naslanja na koncept palanke (neprevedljiv izraz, približen opis bi bil "provincialno, malomeščansko mestece»), ki ga je razvil legendarni srbski mislec Radomir Konstantinović v prelomni knjigi Filosofija palanke iz l. 1969. Mimogrede: ta ključna analiza je $\mathrm{v}$ zadnjem času ponovno deležna posmehljivega razvrednotenja s strani srbskih nacionalistov, na kar v svoji apologiji Konstantinovića upravičeno opozarja Latinka Perović. S pridom pa se Filip David sklicuje tudi na pionirsko kritiko služnosti intelektualcev nacionalistični vulgarnosti, ki jo je Julien Benda napisal že daljnega leta 1927 v knjigi La trahison des clercs, kar so svojčas površno prevajali kot Izdajstvo uradnikov, $\mathrm{v}$ skladu z avtorjevo intenco rabe srednjeveškega pomena besede clerc ("pisar") pa pravzaprav pomeni Izdajstvo intelektualcev.

V kontekst analize teme Književnost in nacionalistična ideologija sodi tudi dolg pogovor, ki sem ga opravil s Tarasom Kermaunerjem, naslovljen »O komunizmu in nacionalizmu, književnosti in politiki, Sloveniji in Jugoslaviji, bolečini in Bogu "(19-61), v katerem Kermauner razgrinja polemično stališče do slovenskih nacionalistov. Prav v obdobju, ko so se odnosi v jugoslovanski federaciji začeli resno krhati in se je Društvo slovenskih pisateljev uprlo diktatu ponovne ideološke unifikacije tako kompleksne državne tvorbe, Nova revija pa je februarja 1987 objavila 57. številko s prelomnimi Prispevki za slovenski nacionalni program, je Kermauner začel objavljati kritike slovenskega nacionalizma ("gentilizma«), kar je nato strnil v dveh medsebojno povezanih knjigah, Pismo slovenskemu prijatelju in Pismo srbskemu prijatelju (oboje 1989), v katerih je opozoril, da princip bratske ljubezni, ki jo nacionalistična ideologija dviga na vrednostni piedestal, pomeni smrtni objem in bratomor. Njegova analiza se je nekaj let pozneje, ob izbruhu jugoslovanskih vojn, izkazala za preroško, vendar je ob izidu pripeljala do ostrih polemik med Kermaunerjem ter vodilnimi filozofi in pisatelji Nove revije. Moj položaj je bil paradoksalen: kot eden izmed ustanoviteljev Nove revije sem po odstavitvi odgovornega urednika Dimitrija Rupla in glavnega urednika Nika Grafenauerja zaradi proskribirane 57. številke 
postal - na predlog uredništva in zbora sodelavcev - vršilec dolžnosti glavnega in odgovornega urednika Nove revije. Edini spor, ki sem ga $\mathrm{v}$ tem skrajno napetem in z veliko medsebojno solidarnostjo zaznamovanem obdobju imel s "trdim jedrom " Nove revije, je zadeval prav objavljanje kritičnih Tarasovih analiz. Iskreno povedano, sem tu kratko malo vsilil svojo voljo in naprej objavljal Tarasa.

Povsem logično je, da je na straneh Sarajevskih zvezkov nenehno odzvanjala nedavno končana vojna. Velik del objavljene proze in poezije je poskušal umetniško artikulirati še sveže rane in grobove, tej travmi pa je bil posvečen tudi intenziven miselni napor. Eden izmed rezultatov je bil v 5. številki (2004) tematski sklop Vojna pisava (Ratno pismo). Nirman Moranjak Bamburać v članku "Ali je kaj vojne v vojni pisavi? « zastavlja temeljno vprašanje možnosti in nemožnosti govora o vojni po vojni. Tako kot je Adorno sežel vso grozo druge svetovne vojne v stavku, da "po Auschwitzu poezija ni več možna«, je bosanska profesorica zajela stisko pričevanja o vojni »med molkom in kletvico«, kot se glasi podnaslov (79).

V dvojni številki 6/7 (2004) so Sarajevski zvezki načeli veliko in občutljivo temo - Neevropska Evropa. Uvodni tekst s pomenljivim naslovom »Vzhod, 'temna stran' Evrope« je prispeval - kdo drug?! Aleš Debeljak. Izjemno zabaven, a z dvojnim dnom temne resnice, je esej Andreja Blatnika "Mickey Mouse potuje na Vzhod"s podnaslovom »Kulturne spremembe v postkomunistični Evropi«, kjer s pomočjo disneyjevskega imaginarija metaforično opiše kulturne spremembe v nekdanjih socialističnih državah po političnih spremembah. Razliko med "pred" in "potem" udarno definira s formulacijo "komunistična represija, postkomunistična depresija« (145). Dragan Velikić je naslovil svoj duhoviti in grenki esej s pomenljivim naslovom "Evropa 'B'« (149).

Hrvaški filozof Žarko Paić je svojo analizo »Prevladovanje Zahoda?» podnaslovil kot "Zablode okcidentalizma«, ki ga definira kot površno ideološko kritiko Zahoda:

$S$ prevzemanjem že zaključenega koncepta Saidove kritike orientalizma sta avtorja Avishai Margalit in Ian Buruma objavila kontroverzen esej, naslovljen Occidentalism. Za njiju je pojem okcidentalizma kratko malo vsota podob in idej o Zahodu v glavah tistih, ki ga sovražijo. Esej izhaja iz teze, da je sedanje sovraštvo Vzhoda do Zahoda, pri čemer se to nanaša predvsem na dežele t. i. Tretjega sveta ob levičarskih in desničarskih kritikah Amerike v Evropi, rezultat zgodovinske tendence boja zoper univerzalizem razsvetljenskega projekta novega veka. (169) 
$\mathrm{V}$ kontekstu vseh teh tem smo neizogibni in neusmiljeni refleksiji morali izpostaviti tudi pojma Balkana in balkanizacije.

Pojem balkanizacija, ki ga je mednarodna politična terminologija pogosto uporabljala ob prelomu 19. in 20. stoletja (nedvomno v zvezi z dramatičnimi zgodovinskimi konflikti, ki so prek dveh balkanskih vojn pripeljali do prve svetovne vojne), je sto let pozneje doživel reaktualizacijo, ker je žal posledica tragičnih vojn na ozemlju nekdanje Jugoslavije. Balkan je ponovno postal karseda negativen in celo zaničljiv pojem, kar se vidi tudi po tem, da se ga vsi otepajo: Italijani in Avstrijci trdijo, da se Balkan začenja na meji s Slovenijo, Slovenci trdijo, da se Balkan začenja na meji s Hrvaško, Hrvati trdijo, da se Balkan začenja na meji s Srbijo, Srbi sprejemajo izraz Balkan le kot zemljepisno, ne pa tudi politično oznako za svojo družbeno stvarnost itd. itd. Za časa skupnega življenja v federalni Jugoslaviji smo Slovenci pojem Balkan razumeli kot slabšalen simbol za kulturno, ekonomsko in politično zaostalost, kot prostor, kjer vladajo čustva, ki so večinoma divja in agresivna, kot nasprotje zaželenemu principu racionalnega urejanja medčloveških razmerij ... Skratka: Balkan je v nereflektiranem vsakdanjem žargonu učinkoval kot simbolno nasprotje edino zveličavnemu pojmu Evrope (v smislu Zahodne Evrope, od osemdesetih let dalje tudi Srednje Evrope), kamor Slovenci tako radi projiciramo svojo zgodovinsko in kulturno pripadnost. Zato smo nekoliko nejevoljni, da nas politični žargon administracije Evropske unije uvršča na Zahodni Balkan, kakor se glasi najnovejša geopolitična oznaka.

V kulturi južnoslovanskih narodov je pojem Balkan doživljal tudi pozitivna ovrednotenja; spomnimo se pojma »balkanskega barbarogenija«, ki ga je srbski avantgardist Ljubomir Micić lansiral v dvajsetih letih, pesmi »Krvava pravljica» (»Krvava bajka») srbske pesnice Desanke Maksimović o nacističnem streljanju otrok 21. 10. 1941 v Kragujevcu, na brdovitom Balkanu, ali pa hvalnice »Balkane moj« zagrebške rock skupine Azra v osemdesetih letih. Vendar je vrtinec zgodovine odpihnil te pozitivne vrednostne artikulacije in $\mathrm{v}$ splošni zavesti uveljavil razumevanje Balkana kot sinonima za zlo. Diametralno nasprotna je idealizacija Balkana, značilna za t. i. jugonostalgijo, ki pa je prav tako slepa za zgodovinsko realnost ter nagnjena $\mathrm{k}$ idealiziranju nekdanjega »bratstva in enotnosti«, ne da bi razumela, da je ideološko povzdigovanje sožitja zabrisovalo realne probleme in zgodovinske rane ter bistveno prispevalo k temu, da je Jugoslovanska »ljudska" armada - dinozavrski ostanek virulentnega stalinizma - v smrtonosnem objemu z Miloševićevim nacionalizmom l. 1991 pahnila Balkan nazaj h krvavemu pomenu svojega imena. 
Imaginarij Balkana je z lucidnostjo in občutljivostjo, ki še danes vzbujata občudovanje, zahodnim kulturam približala angleška pisateljica Rebecca West z obsežnim potopisom "Črno jagnje in sivi sokol» (Black Lamb and Grey Falcon), ki je sad njenih potovanj po Jugoslaviji proti koncu tridesetih let. Sicer pa zahodna javnost uporablja pojem Balkan kot oznako za regijo, kjer vladajo neusmiljeni spopadi na podlagi etničnih in religioznih razlik. Mediji v Zahodni Evropi in Severni Ameriki so pogosto definirali vojne v nekdanji Jugoslaviji kot plemenske vojne (»tribal wars»). Ta oznaka vsebuje prezirljiv podton in je rezultat prikrite arogance domnevno civiliziranega sveta, ki se zgraža nad primitivnimi razlogi za te vojne, fanatično zaslepljenostjo bojevnikov in njihovimi krvavimi metodami.

$\mathrm{V}$ malone vsaki številki smo objavili tudi rubriko (ponavadi kot uvodnik), ki se je na jezikih, ki jih slovanski lektorati na svetovnih univerzah zdaj poučujejo pod skupno kratico BCMS (Bosnian, Croatian, Montenegrin, Serbian) imenovala "U PRVOM LICU«, v slovenščini pa bi se glasila z zgoščeno eleganco pojma »PRVOOSEBNO «. V številki 6/7 jo je zapolnil Mirko Kovač (1938-2013) s pretresljivimi spomini na vprašanje svoje identitete - \#rvat po očetu, Črnogorec po materi, ki ga je dojila muslimanka« (13) - ter na različne obtožbe in grožnje, ki jih je bil deležen zaradi svoje etnične »nečistosti«. Ta rasni pripovednik in humanist je bil izbrisan iz srbskega literarnega kanona, ker se je 1. 1991 uprl Miloševiću in demonstrativno zapustil Srbijo; odtlej je živel v Rovinju, kjer je l. 2013 tudi umrl. Čigav pisatelj je torej Mirko Kovač - črnogorski, srbski ali hrvaški? Vseeno. Dober pisatelj je.

Dvojna številka 8/9 (2005) je bila posvečena delikatnemu in eksplozivnemu vprašanju »Nacionalnega literarnega kanona«. Seveda: vprašanje kánona je še posebej občutljivo in kot neeksplodirana bomba nevarno $\mathrm{v}$ trenutku, ko utihnejo kanóni in se strategija osvajanja teritorija preseli z bojnega na literarno oz. jezikovno polje. Profesorica komparativistike s sarajevske univerze Nirman Moranjak Bamburać je v uvodnem članku »Težave s 'kanonizacijo' « udarno in nazorno ilustrirala problem refleksije in intelektualne artikulacije kanonizacijskega početja:

Kdo je sploh poklican, da govori o taki temi, kot je nacionalni literarni kanon? Tisti/-e, katerih pripadnost in lojalnost sta prežeti s tako intenzivnimi čustvi, da se jim normativne in orientacijske vrednosti takega kanona zdijo samoumevne? Ali tisti/-e, katerih »dokazana« nelojalnost naredi slednjo razpravo za brezpredmetno? Pisatelji/-ce, kritiki/-čarke, teoretiki/-čarke, študentje/-ke književnosti? [...] Elita ali množično občinstvo? (51) 
Miško Šuvaković, profesor na Glasbeni akademiji v Beogradu ter mednarodno priznani strokovnjak za zgodovino avantgarde, je prispeval analizo $s$ topovsko udarnim naslovom "Mnogostranski obrazi kanona: Канон ali kanoni (množica vprašanj z odgovori)«:

Vprašanje o kanonu je politično vprašanje. To vprašanje je politično, ker kanon ni zgolj preprosta vsota estetskih, umetniških, literarnih, kulturnih, etičnih in družbenih norm (navad, pravil, vrednot, kriterijev, zavestnih odločitev, brezinteresnih sodb). [...] Vprašanje o kanonu ni nevtralno vprašanje aksiološko orientirane estetike, temveč teorije kulture, ko se sprašuje o ideoloških aparatih ter njihovih številnih in večpomenskih učinkih v konkretnih zgodovinskih in zemljepisnih praksah. (111)

Naj mi bo dovoljena (avto)biografska digresija: z Miškom sva bila sošolca na osnovni šoli »22. decembar« v Beogradu. To dejstvo tu navajam zato, da bi na anekdotičen način poudaril, kako zelo smo bili pisatelji in intelektualci v nekdanji Jugoslaviji medsebojno povezani in kako globoko in boleče so vojne zarezale $\mathrm{v}$ to skupno človeško tkivo. Zato ni naključje, da je razredni časopis Pionirski list, v katerem sva oba pri starosti desetih let začela literarno pot, našel svoj spominski odmev tudi v mojem epu Vrata nepovrata (1. knjiga: Zemljevidi domotožja, 2. zvezek: Zgodovinski atlas zapuščenih domovanj, 27. spev: »Redakcije«). In če je bil Pionirski list Miškova in moja "Prva redakcija", potem so Sarajevski zvezki bili "druga redakcija" (Novak, Zemljevidi 280).

Ostro kritiko kanonizacije izpelje tudi sarajevski literarni zgodovinar in univerzitetni profesor Enver Kazaz: v članku Nacionalni literarni kanon - mesto moči ugotavlja, da je "zgodovina kanona v južnoslovanskem kulturnem prostoru enaka zgodovini podrejanja literarne vede nalogam politične ideologije» (124).

Ker se je radikalno prevrednotenje literarnih kanonov v novonastalih državah na ozemlju nekdanje Jugoslavije zgodilo na podlagi absolutizacije principa nacionalne pripadnosti, se je najhuje godilo tistim pisateljem, ki s svojim poreklom, imenom in pogledi niso potrjevali identitetnega etničnega kriterija. Naj kot primer vzamem Josipa Ostija, sarajevskega pesnika, ki je začel svojo pot v okviru avantgardističnega gibanja in se uveljavil kot eden izmed vodilnih bosanskih pesnikov. Začetek vojne ga je presenetil med bivanjem v Sloveniji, kjer si je ustvaril nov dom ... tudi v umetniškem smislu. Ustvaril je nekaj najlepših pesniških zbirk, kdaj koli napisanih v slovenskem jeziku. Pomenljiva je primerjava njegovega slovenskega pesniškega opusa in prejšnje poezije, napisane v »jeziku mojih spominov«, kot ga Osti posrečeno imenuje: 
Čeprav se navezuje na bistvene značilnosti Ostijeve pesniške govorice (plodna sinteza lirske zgoščenosti in pripovednega loka, na ljudsko ritmiko naslonjenega verza ter svežih podob), se zdi, kot da bi ob prestopu v drug in drugačen jezik Ostijev pesniški glas doživel določene spremembe v tonaliteti: pesmi zvenijo mehkeje, kot da bi mu slovenščina pomagala, da vzpostavi distanco do tragedije $\mathrm{z}$ vojno uničene bosanske domovine. Pesmi, ki pričujejo o grozi vojne, so še zmeraj polne bolečine, vendar je ta bolečina čista in presvetljena, izkristalizirana skozi prizmo jezika, ki ga vojna ni razdejala. [...] Če je Ostijeva "bosanska" poezija imela v sebi marsikaj epskega, je za njegovo slovensko poezijo značilna radikalna lirizacija. To seveda ne pomeni, da Osti ne uporablja več pripovednih postopkov. Obratno: narativnost ostaja ena izmed poglavitnih značilnosti njegove poezije, a zdaj služi lirskemu, povsem osebnemu videnju sveta, ki ga izreka izraziti lirski subjekt, medtem ko je prej bila vključena v pripovedovanje kolektivnih zgodb. (Novak, Izgon 385-386)

In vendar se ta izjemni pesnik sooča z zagatnim problemom: ker ne pripada nobenemu izmed treh konstitutivnih narodov $\mathrm{BiH}$ (ne Bošnjakom ne Srbom ne Hrvatom), je bolj ali manj izbrisan iz zgodovine književnosti $\mathrm{BiH}$, ki jo po tragičnih vojnah določajo kanoni teh treh etnij. Ker pa je treba zmeraj pomesti tudi in predvsem pred lastnim pragom, bodi povedano tudi naslednje: čeprav je Osti iz slovenščine prevedel 136 knjig, je le stežka dobil slovensko državljanstvo. In čeprav je eden izmed najbolj prevajanih avtorjev in tudi med slovenskimi ljubitelji književnosti izjemno priljubljen, ga slovenska literarna zgodovina, še zmeraj nacionalistično bornirana, ne obravnava kot "našega pesnika«. Tem slabše za »nas«!

V številki 27/28 (2010) je objavljen tematski blok Tranzicija in kultura. Enver Kazaz v uvodnem članku »Tranzicijska etnokulturna puščava" z grenko ostrino razgrinja nemožnost Bosne in Hercegovine, da se iztrga iz smrtonosnega primeža vojne: »Bosanskohercegovska tranzicijska, z etnonacionalizmom razdrta in razdeljena družba je zaznamovana $\mathrm{z}$ nemožnostjo izhoda iz kolektivnih travm vojne.«(83)

Tatjana Rosić, literarna zgodovinarka iz Beograda, vidi v članku "Slepa pega realnega" temeljni »škandal tranzicije» v manipulacijah medijev in marketinga (149).

$\mathrm{V}$ kontekstu številke, posvečene temi Tranzicije in kulture, pa tudi refleksiji nacionalizmov ter demonizacije drugih in drugačnih, je izjemno zanimiv in ploden prispevek Mirta Komela Kultura in nacinalizem, ki se končuje z lucidno pohvalo in kritiko romana Gorana Vojnovića Čefurji raus!:

Tisto, kar je Vojnovićeva največja zasluga, je hkrati tudi njegov največji problem: omogočil je "Slovencem«, da se legitimno norčujejo na račun " Čefurjev», 
to pa je lahko storil le tako, da ga je izgovoril iz pozicije "Čefurja» (kakor že Magnifico). Vojnović je iz tega zornega kota prenehal biti »največji Čefur« in je postal največji »Slovenec«. (338)

Ena izmed ključnih tem je bila Nomadizem v št. 23/24 (2009). Uvodnik "Zemljevidi za potepuhe: nomadizem in kaos konca zgodovine« je prispeval hrvaški filozof Žarko Paić, ki upravičeno opozarja:

Smisel nomadizma danes v dobi konca zgodovine se ne nanaša na nič literarnega. Ne gre za nikakršno literarno figuro, za nikakršno literarno ali umetniško gibanje. Nomadizem je v tem smislu zgolj metafora za stanje nenehnega gibanja pri potovanju po svetu, odkar je po obdobju zahodnjaške kolonizacije svet postal prostor-čas kapitalistične ekspanzije. Nomadizem ni nikakršno duhovno stanje občutja nepripadanja in nezakoreninjenosti v prostoru razvoja moderne nacije-države. Ta modni pojem se je razširil po prelomnem spisu poststrukturalizma Gillesa Deleuzea / Felixa Guattarija Anti-Ojdip v sedemdesetih letih 20. stoletja. V njunem delu ima nomadizem povsem drugačen pomen od toliko opevanega umetniškega sinonima za postmoderne potepuhe po svetu kot blodnjaku novih medijev. (108-109)

Številka 43/44 (2014) je bila posvečena stoletnici Velike vojne. Uvodnik "De te fabula narratur: 1914« je napisal Lev Kreft. Začne se z resnico, ki ji ni mogoče oporekati: "Moč in zgodovina sta v trajni partnerski zvezi, " (13) konča pa z lucidno in grenko ugotovitvijo:

Povod prve svetovne vojne [...] ni bil atentat 1. 1914, temveč aneksija Bosne in Hercegovine. Stališče, ki ga je zavzela socialdemokracija, tako tista balkanska kot tista svetovna, pa je bilo uvod v poznejšo podporo socialdemokracije vojni, v njen razpad na komunistično in socialdemokratsko mednarodno gibanje ter v neslavno vlogo, ki jo je njen največji del odigral pri gašenju povojne revolucije v Evropi. (21)

Pisateljica Daša Drndić (1946-2018) je prispevala spominsko besedilo „Vojaški Tanz« (»Ratni Tanz«), v katerem priklicuje spomine na svojega deda, vojaka v Veliki vojni:

Galicija, Galicija, je ponavljal moj ded. Ob litrčku malvazije iz lastnega vinograda, kamor je rad primešal tudi nekaj žlic medu svojih čebel, je pripovedoval in pripovedoval, jaz pa sem slišala le Galicija, Galicija. Imela sem sedem let. In tudi pozneje, vse dokler smo poleti odhajali v srce Istre, vse dokler moj ded ni umrl, je Galicija vselej prisedla za mizo. Moj brat in jaz sva zajtrkovala skupaj z Galicijo, in z Galicijo sva odhajala spat.

Galicija se je kotalila po sobah kot skrivnost, kot črna pernata žogica, ki se je zdaj večala in zdaj manjšala, da bi na koncu, nikoli ujeta, odskakljala v mit. 
Galicija ni bila lepa, bila je zastrašujoča, tako skrivnostna in meglena. Nikoli do konca razumljena, nikoli do konca slišana. (111)

Daša Drndić je ena izmed ključnih pisateljic te regije; med drugim je z mojstrsko, presunljivo besedo osvetlila mnoge temne strani naše skupne zgodovine. Naj tu omenim le Sonnenschein (2007), mednarodno odmeven roman, ki ga imamo tudi v slovenščini, zahvaljujoč odličnemu prevodu Đurđe Strsoglavec. Avtorica je tu med drugim na laž postavila floskulo, da fašistična Italija ni preganjala Judov (v roman je vključen imenski seznam judovskih žrtev, ki s svojim skrajnim asketizmom učinkuje pošastno in inovativno razširja izrazne možnosti romaneskne umetnosti), med drugim pa je opisala tudi usodo Judov na slovenskih ozemljih, temo, ki - z izjemama romanov Marpurgi Zlate Vokač Medic in Biljard pri Dobrayju Dušana Šarotarja - predstavlja slepo pego slovenske književnosti. (Mimogrede: paradoksalna specifika endemičnega slovenskega antisemitizma je, da gre za antisemitizem brez Judov.) V tem kontekstu bodi povedano tudi to, da je prav Daša Drndić prva, ki je - prav v tem romanu - na dokumentaren način osvetlila pošastno vlogo nacističnega zločinca Odila Globočnika, našega domačega, slovenskega nacističnega klavca, ki je prenovil in izmojstril tehniko pogona množičnega pobijanja.

Naj bo v tem pričevanjskem zapisu dovoljeno dodati, da sva se z Dašo veliko pogovarjala o najini skupni življenjski izkušnji - življenju v Beogradu. Tam je Daša srečno preživela večino svojega življenja (delala je kot radijska novinarka), začetek jugoslovanskih vojn pa jo je prisilil, da se je vrnila v domovino svojih staršev, na Hrvaško. Zadnjič sem jo srečal na pogrebu Aleša Debeljaka februarja 2016.

Sarajevski zvezki so nenehno posvečali kar največjo pozornost živi literarni produkciji. Petdeset številk te revije predstavlja najboljšo možno antologijo literature te regije na začetku 21. stoletja. Nekatere številke pa so bile še posebej posvečene literarnim vrstam in drugim umetnostim: dvojna številka 11/12 (2006) sodobni drami, številka 14 (2006) sodobni prozi, dvojna številka 15/16 (2007) sodobni poeziji, številka 17 (2007) pa sodobni kritiki.

Številka 21 (2008) je bila posvečena temi Mesto. Uvodnik, naslovljen »Pisatelj in mesto«, je napisal Mirko Kovač: "Z mesti je tako kot z ljudmi; znajo vam biti ljubi, simpatični ali zoprni; vanje se lahko zaljubite na prvi pogled ali zgradite trajno prijateljstvo. Mesto je živo bitje ...«(13)

Samo po sebi se razume, da je bil kot vrhunska avtoriteta za vprašanje mest k sodelovanju povabljen vizionarski nekdanji župan Beograda, 
arhitekt Bogdan Bogdanović, ki je zaradi kritike diktatorskega in militarističnega Miloševićevega režima skupaj z ženo pokončno odšel v eksil na Dunaj. Prav Bogdanović je podal eno izmed najbolj lucidnih analiz razlogov tragičnih vojn $\mathrm{v}$ nekdanji Jugoslaviji: $s$ terminom urbicid je prodorno definiral grozljiv pojav rušenja mest (Vukovarja, Dubrovnika, Sarajeva, Starega mostu v Mostarju itd.), ki je značilen za sovražno nasilje primitivne ruralne kulture nad urbano. Če smo čisto natančni, za izbruh nasilja do mest ni kriva ruralna kultura kot taka, saj temelji na izraziti etiki; povzročitelji zla v vojnah na tleh nekdanje Jugoslavije so bili ljudje, ki so izgubili arhaično ruralno kulturo, urbane kulture pa nikoli niso osvojili, zato so sovražili mesto kot simbol njim nedosegljivega načina življenja. Resnici na ljubo so inicialno vlogo pri tem genocidnem besu odigrali nekateri intelektualci, pri katerih se žal ne moremo tolažiti, da gre za primitivce, ki ne vedo, kaj počnejo.

Problematika mest je primerna točka $\mathrm{k}$ pritegnitvi premisleka sodelovanja Aleša Debeljaka pri Sarajevskih zvezkih.

Gre za osrednjega pesnika slovenskega postmodernizma, saj je v osemdesetih letih na umetniško močan in inovativen način izrazil razpršeno, drseče eksistencialno občutje časa "po koncu« časa (Imena smrti, 1985; Slovar tišine, 1987). Zato sem sintetično študijo o njegovi poetiki pred leti naslovil "Aleš Debeljak, pesnik poznega časa" (Zven in pomen: študije o slovenskem pesniškem jeziku, 2005). Pozneje se je odmaknil od esteticistične samozadostnosti pesniškega jezika $\mathrm{k}$ čedalje bolj izrazitemu upesnjevanju izvenjezikovne stvarnosti, kar je bilo znamenje naraščajoče zavesti o bivanjski odprtosti v svet in ranljivosti posameznika; ta metamorfoza prihaja do besede v zbirki Mesto in otrok (1996), kjer radikaliziranje jezikovne in estetske strategije dobi tudi etično utemeljitev. Naslov Mesto in otrok gre torej razumeti kot razpetost med tragično izkušnjo zgodovine in izkušnjo rojstva otroka, ki vzbuja upanje. Obe izkušnji - smrt mest in rojstvo otrok - sta pesnika pripravili do skrušene skromnosti pred človeško usodo. Mesto in otrok je poezija Groze in Radosti. K tematiki mesta se Debeljak vrne v zbirki Tihotapci (2009) ter v svoji zadnji, čudovito poetični knjigi pesmi v prozi Kako postati človek (2015), kjer upesnjuje Ljubljano svojega otroštva. Ta zbirka bi s svojim odkritim, avtobiografskim tonom lahko pomenila nov začetek v razvoju Debeljakove poetike, če je ne bi nenadna pesnikova smrt 28. 1. 2016 za vselej spremenila $\mathrm{v}$ poslednjo.

Tu žal ni mogoče analizirati Debeljakovega znanstvenega delovanja na poljih literarne vede, sociologije kulture in religiologije. Naj tu zgolj skiciram njegov dramatičen intelektualni in znanstveni razvoj od 
pionirja teorije postmodernizma na Slovenskem (Postmoderna sfinga, 1989) prek premisleka razmerja med literaturo in narodom (Individualizem in literarne metafore naroda, 1998; The Hidden Handshake: National Identity and Europe in the Post-Communist World, 2004) do lucidne in pretresljive refleksije usode književnosti in književnikov na območju nekdanje Jugoslavije (Balkanska brv: eseji o književnosti "jugoslovanske Atlantide", 2010). Prav s podobo mitične potopljene Atlantide je izrazil uničevalno resnico zgodovine ter bistveno vplival ne le na intelektualno ozračje Sarajevskih zvezkov, temveč tudi na temeljno orientacijo literarne zgodovine, ki raziskuje poetike in nesrečne usode kroga vrhunskih pisateljev in pisateljic po razpadu Jugoslavije, raztresenih po svetu, v orbito eksilantov in nomadov, ali ujetih v notranjo emigracijo.

V pesniški zbirki Pod gladino (2004) je nosilna metafora potapljanja pod gladino in utopitve. Debeljak jo je pozneje uporabil tudi v izvenpesniškem kontekstu, kot temeljno definicijo svoje literarnozgodovinske, kulturološke in sociološke raziskave fenomena "jugoslovanske Atlantide«. Kot sem zapisal v svojem poslovilnem govoru, ki sem ga prebral na Aleševem pogrebu (Novak, In memoriam 35):

Južnoslovanske književnosti so revnejše za literarnega zgodovinarja, ki jim je pretanjeno prisluhnil v času vesoljnega potopa, potapljača in podvodnega arheologa, edinega, ki se je bil sposoben s spominsko kapaciteto svojih pljuč na dah potopiti do dna potopljene Atlantide, kot je poimenoval kulturno zavest, ki je izginila s političnih zemljevidov sveta.

Pod gladino je zagledal sanjske podobe s koralami spomina obraslih ruševin.

V številki 49/50 (2016) so objavljeni kar trije nekrologi za Alešem; napisali smo jih Vojka Smiljanić Đikić, Mihajlo Pantić in jaz. Naj citiram začetek in konec Vojkinega slovesa od Aleša, ki je naslovljen "Kako se začne ljubezen" in za katerega se je izkazalo, da je napoved Vojkinega konca in konca Sarajevskih zvezkov:

Kako se je začelo? To je najbrž najtežje vprašanje. Ljudje se najbolj spominjamo konca. Vsi se seveda spominjamo tistega, kar je preteklo, začetek pa se vsem izmika. Tako da se moram vrniti v dneve, ko smo sanjali Sarajevske zvezke.

Ko smo se začeli zbirati okoli te ideje, sem se med Slovenci najprej spomnila - Borisa Novaka. Vzljubila sem ga že v času vojne. Ko smo ostali sami, ni zgolj prihajal, temveč je v oblegano Sarajevo prinašal pomoč. Vsem pisateljem. Zdaj pa pripravljamo redakcijo, Boris, seveda, a potrebovali smo še nekoga iz Slovenije. Pokličem Borisa, on pa kar takoj: Aleš Debeljak. Nato zavrtim še nekaj številk v Ljubljani. In poglejte zdaj mojo neobveščenost. Povedo mi, saj on je v Sarajevu, govori v Muzeju književnosti. O Prešernu. [...] 
Nisem pristopila $\mathrm{k}$ Alešu, sedla sem na atrij iz granitnih kock pod kupolo vedrega večernega neba. Čakam, da začne. Na oder pride mlad, vitek človek, napet kot lok puščice, in z zvonkim glasom, brez kakšnega posebnega uvoda, prične govoriti o svoji veliki ljubezni, Prešernu. To ni bilo predavanje, bila je to pesem o pesmi Prešernovi. Ena sama velika strast, oblikovana kot slap besed. [...]

Nekoč mi je med pogovorom dejal: „Veš, ko sem vstopil v redakcijo Sarajevskih zvezkov, sem verjel, da bo to le ena izmed mojih dejavnosti. Zdaj, kadar se v kabinetu ozrem in za hrbtom vidim ta niz petdesetih zvezkov, pa se mi zdi, da je bila to najvažnejša stvar, na kateri sem delal.«

Dragi moj Aleš, kaže, da je zate vse, kar si delal, bilo najvažnejše. (371-372)

Lep je tudi nekrolog srbskega literarnega zgodovinarja in pisatelja Mihajla Pantića, ki je priklical spomin na srečanje z Alešem na neki literarni manifestaciji v Splitu 1. 1985:

Ko je moderator izgovoril: - Aleš Debeljak, sem se spomnil pesmi, ki sem jih, podpisane s tem imenom, bral po revijah. Tam, na odru, pod steklenim zvonom reflektorske svetlobe, ki je zgoščala temo, je govoril svoje stihe z mirnim, ravnim, nekoliko melanholičnim glasom. V spominu mi je ostal, mallarméjevsko, le zven. Tisto noč, ko sem si zaželel, da bi se naučil slovensko, sem spoznal Aleša. (381)

Kmalu za Alešem se je poslovila tudi Vojka. Z njunim odhodom so se najbrž poslovili tudi Sarajevski zvezki. Ne izhajajo več. Z njuno smrtjo je postalo kristalno jasno, da sta bila Vojka in Aleš nepogrešljiva motorja projekta, naslovljenega Sarajevski zvezki. Vojka s svojo neizmerno energijo in Aleš s svojo etično voljo in briljantnim umom.

Ko zdaj končujem ta spominski, pričevanjski zapis, glede katerega me navdaja slab občutek, da se je sprevrgel v mešanico boleče nostalgije in nepopolnega seznama nedokončanega projekta, pa razločno čutim, da so bili Sarajevski zvezki najbolj avtentičen, etično pošten, umetniško in intelektualno ambiciozen poskus artikulacije novega položaja književnosti in pisateljev na teh prostorih po padcu Jugoslavije.

Do konca časa si bodo te kulture in ti jeziki medsebojno blizu, kljub vsem mejam. Zato je le vprašanje časa, kdaj se bo pojavil nov projekt literarnega mostu, Sarajevski zvezki.

V zvezi s Sarajevskimi zvezki sem v svojem poslovilnem govoru na pogrebu Aleša Debeljaka povedal tudi naslednje:

Redakcija Sarajevskih zvezkov je revnejša za enega svojih ustanoviteljev in visokooktanski motor povezovanja pisateljev, razdeljenih z mejami.

Hotel Evropa v Sarajevu je revnejši za najbolj načelnega Evropejca, 
ki je kdaj tam spal ... pardon: cele noči bedel in debatiral, in Evropa je revnejša za najpametnejšega in najbolj strastnega zagovornika Sarajeva in Bosne. Ko sva tam nekega jutra pila prvo kavo in deseti viski, sva skandirala v ritmu deseterca: Jebeš zemlju / koja Bosne nema - jebeš Evropu / koja Bosne nema! (33-34)

\section{LITERATURA}

Albahari, David. »Granice«. Sarajevski zvezki 3 (2003): 59-64.

Blatnik, Andrej. "Miki Maus putuje na Istok (kulturne promene u postkomunističkoj Evropi)«. Sa slovenačkog prevela Ana Ristović Čar. Sarajevski zvezki 6/7 (2004): $133-148$.

Bogdanović, Bogdan. „O sreći u gradovima«. Sarajevski zvezki 21/22 (2008): 57-60.

Ćosić, Bora. "Povratak iz progonstva". Sarajevski zvezki 3 (2003): 35-58.

David, Filip. "Nacionalizam kao ideologija». Sarajevski zvezki 4 (2003): 77-79.

Debeljak, Aleš. Postmoderna sfinga. Celovec - Salzburg: Založba Wieser, 1989.

Debeljak, Aleš. Individualizem in literarne metafore naroda. Maribor: Založba Obzorja, 1998.

Debeljak, Aleš. The Hidden Handshake: National Identity and Europe in the Post-Communist World. Prev. Aleš Debeljak in Rowley Grau. Lanham; Boulder; New York; Toronto; Oxford: Rowman \& Littlefield Publishers, 2004.

Debeljak, Aleš. »Istok, 'tamna strana' Evrope«. Prevela Farah Tahirbegović. Sarajevski zvezki 6/7 (2004): 77-79.

Debeljak, Aleš. Pod gladino. Ljubljana: Mladinska knjiga, 2004.

Debeljak, Aleš. Balkanska brv: eseji o književnosti "jugoslovanske Atlantide«. Ljubljana: Študentska založba (Beletrina), 2010.

Drakulić, Slavenka. Intelektualci kao loši momci. Sarajevski zvezki 4 (2003): 71.

Drndić, Daša. Sonnenschein. Prevedla Đurđa Strsoglavec. Ljubljana: Modrijan, 2009.

Drndić, Daša. »Ratni Tanz«. Sarajevski zvezki 43/44 (2014): 111-114.

Kazaz, Enver. »Prizori uhodanog užasa«. Sarajevski zvezki 8/9 (2005): 123-134.

Kazaz, Enver. "Nacionalni književni kanon - mjesto moći«. Sarajevski zvezki 5 (2004): 137-166.

Kazaz, Enver. »Tranzicijska etnokulturna pustinja«. Sarajevski zvezki 27/28 (2010): 83-102.

Kermauner, Taras. Pisma srbskemu prijatelju. Celovec: Drava, 1989.

Kermauner, Taras. Pisma slovenskemu prijatelju. Celovec: Drava, 1989.

Kermauner, Taras, in Boris A. Novak. "O komunizmu i nacionalizmu, književnosti in politiki, Sloveniji in Jugoslaviji, bolečini in Bogu«. Prev. Ana Ristović. Sarajevski zvezki 4 (2003): 19-61.

Komel, Mirt. »Kultura i nacionalizam«. Sarajevski zvezki 27/28 (2010): 335-337.

Kovač, Mirko. »(Ne)prilagođen«. Sarajevski zvezki 6/7 (2004): 9-22.

Kovač, Mirko. »Pisac i grad«. Sarajevski zvezki 21/22 (2008): 13-17.

Kreft, Lev. "De te fabula narratur: 1914«. Sarajevski zvezki 43/44 (2014): 13-21.

Krese, Maruša. Pesmi. Ur. Amalija Maček. Spremni besedi Amalija Maček in Boris A. Novak. Novo mesto: Goga, 2019.

Matvejević, Predrag. Predlog za razmišljanje. Sarajevski zvezki 4 (2003): 69-70.

Matvejević, Predrag. Mediteranski brevir: spremenjena in dopolnjena izdaja. Prev. Vasja Bratina. Ljubljana: V. B. Z., 2008. 
Matvejević, Predrag. Kruh naš. Iz hrvaščine prevedel Vasja Bratina. Ljubljana: V. B. Z., 2009.

Moranjak Bamburać, Nirman. "Ali je kaj smisla v vojni pisavi?«. Sarajevski zvezki 5 (2004): 79-92.

Moranjak Bamburać, Nirman. „Nevolje sa kanonizacijom». Sarajevski zvezki 8/9 (2005): 51.

Novak, Boris A. »Zašto 'pisci na granici'?«. Sarajevski zvezki 3 (2003): 33-35.

Novak, Boris A. "Reči koje teku nasuprot toku vremena, uvek iznova». Sarajevski zvezki 3 (2003): 125-140.

Novak, Boris A. "Aleš Debeljak, pesnik poznega časa«. Boris A. Novak. Zven in pomen: študije o slovenskem pesniškem jeziku. Ljubljana: Znanstvenoraziskovalni inštitut Filozofske fakultete, 2005. 247-269.

Novak, Boris A. "Izgon v raj: dvojezični pesniški glas Josipa Ostija«. Josip Osti. Izgon $v$ raj: izbrane pesmi. Izbral in spremno besedo napisal Boris A. Novak. Prev. Jure Potokar, Boris A. Novak in Josip Osti. Ljubljana: Mladinska knjiga (Kondor), 2012. 371-421.

Novak, Boris A. Vrata nepovrata (epos) - Prva knjiga: Zemljevidi domotožja. Novo mesto: Goga, 2014.

Novak, Boris A. »In memoriam: Aleš Debeljak (1961-2016)«. Sodobnost 80.12 (2016): 32-38.

Novak, Boris A. »In memoriam: Aleš Debeljak (1961-2016)«. Sarajevski zvezki 49/50 (2016): 373-379.

Paić, Žarko. "Prevladavanje Zapada?: zablude okcidentalizma«. Sarajevski zvezki 6/7 (2004): 167-178.

Paić, Žarko. "Zemljovidi za lutalice: nomadizam i kaos kraja povijesti«. Sarajevski zvezki 23/24 (2008): 107-126.

Pantić, Mihajlo. »Aleš Debeljak«. Sarajevski zvezki $49 / 50$ (2016): 381-384.

Petlevski, Sibila. »Književna potraga za izgubljenom istinom i identitetom«. Sarajevski zvezki 3 (2003): 37-54.

Potočnik, Janez. „Our Balkans: The Fragile Heart of Our Europe«. Best of Sarajevo Notebooks II 34 (2011): 911.

Rupel, Dimitrij. "Let's Build Bridges Again«. Best of Sarajevo Notebooks 18 (2008): 5-6.

Rosić, Tatjana. »Slepa pega realnog«. Sarajevski zvezki 27/28 (2010): 149-176.

Smiljanić Đikić, Vojka. »Knjiga mrtvih Smiljanića u Sarajevu«. Sarajevski zvezki 32/33 (2011).

Smiljanić Đikić, Vojka. »Kako počinje ljubav«. Sarajevski zvezki 49/50 (2016): 371372.

Šuvaković, Miško. „Mnogostrana lica kanona: канон ili kanoni (mnoštvo pitanja sa odgovorima«. Sarajevski zvezki 8/9 (2005): 111-122.

Velikić, Dragan. "Granica, identitet, literatura«. Sarajevski zvezki 3 (2003): 65-73.

Velikić, Dragan. »Evropa 'B'«. Sarajevski zvezki 6/7 (2004): 149-154.

Visković, Velimir. "Uvodnik«. Sarajevski zvezki 1 (2002): 7-10.

Visković, Velimir. Ideologi zločina. Sarajevski zvezki 4 (2003): 65-68.

West, Rebecca. Black Lamb and Grey Falcon. A Journey through Yugoslavia. New York: Penguin, 2007. 


\section{Browsing Through the Sarajevo Notebooks in the Mirror of Memory}

Keywords: literature and politics / Yugoslavia / Yugoslave literatures / literary magazins / Sarajevo Notebooks / Europe / Balkan / cultural history / cultural identity / nationalism /emigration

Sarajevo Notebooks were the best Yugoslav literary magazine of all times. It is paradoxical that it was created only after the bloody fall of Yugoslavia, in 2002. (The author, a Slovenian poet and professor of comparative literature, was one of the founding members.) Sarajevo Notebooks had no intention whatsoever to revive the late Yugoslavia. Its ambition was much more modest in the political sense, but the highest possible in the artistic and intellectual sense: to restore the cooperation among writers in the region and to articulate the literary images of the radically changed world after the end of the great utopian stories - after the fall of the Yugoslav project of the "brotherhood and unity" and after the fall of socialism, the political project of the twentieth century which first petrified into a totalitarian dictatorship and at its end, failing to democratize, returned from its grave as a blood thirsty vampire of nationalism. The stones of the Berlin fell to the Balkans. Sarajevo Notebooks detected a deeply changed position of writers and intellectuals in the post-war and post-socialist societies, frequently pushed to the destiny of refugees and emigrants; those writers who stayed "at home," often chose the "inner emigration." Nationalistic ideologies ruling in the newly formed states have radically re-formed literary history in order to achieve "ethnically pure" literary canons. Sarajevo Notebooks reflected the paradoxes of the transition between socialism and the restored "democracy" and "capitalism." The magazine analyzed new relations between the West and the East which in spite of all the changes continued to be a different, "non-European Europe«. Although the formal obituary of the magazine was never written, its end was painfully marked by the deaths of two protagonists, its initiator, the Bosnian poetess Vojka Smiljanić Đikić, and the Slovenian poet and professor of cultural studies Aleš Debeljak, in 2016. Sarajevo Notebooks have accomplished their historical mission, remaining a bright example of solidarity and cooperation between writers belonging to mutually hostile Balkan countries, and an inspiration for the future bridge building projects.

1.02 Pregledni znanstveni članek / Review article

UDK 821.163.09-92"2002/2017“"

070:930.85(497.1)

D0I: https://doi.org/10.3986/pkn.v43.i2.01 